Article

\title{
Development of an Issue-Situation-Based Board Game: A Systemic Learning Environment for Water Resource Adaptation Education
}

\author{
Ping-Han Cheng ${ }^{1}\left(\mathbb{D}\right.$, Ting-Kuang Yeh ${ }^{2,3, *}$, Jen-Che Tsai ${ }^{1}$, Ching-Rong $\operatorname{Lin}^{4}$ and \\ Chun-Yen Chang 1,2,5,*(D) \\ 1 Graduate Institute of Science Education, National Taiwan Normal University, Taipei 116, Taiwan; \\ pinghancheng@gmail.com (P.-H.C.); lansk110792@gmail.com (J.-C.T.) \\ 2 Department of Earth Science, National Taiwan Normal University, Taipei 116, Taiwan \\ 3 Institute of Marine Environmental Science and Technology, National Taiwan Normal University, \\ Taipei 116, Taiwan \\ 4 Department of Tourism, Ming Chuan University, Taoyuan 333, Taiwan; crlin@mail.mcu.edu.tw \\ 5 Science Education Center, National Taiwan Normal University, Taipei 116, Taiwan \\ * Correspondence: tkyeh@ntnu.edu.tw (T.-K.Y.); chunyenc@gmail.com (C.-Y.C.)
}

Received: 31 January 2019; Accepted: 27 February 2019; Published: 4 March 2019

check for updates

\begin{abstract}
Climate change has severely affected water resources (WRs) today, highlighting the importance of promoting education on WR adaptation (WRA). The goal of WRA education is to cultivate learners' cross-oriented system knowledge (COSK), responsibility for WR environment (RWRE), value of public benefits (VPB), and empathy and negotiating thinking (EaNT). This study developed an issue-situation-based board game, namely Water Ark, to enhance participants' WR knowledge. In this study, participants were divided into four groups with each playing the role of a WR-related organization: the government, agricultural sector, industrial sector and public guild. Scales and interviews were used to assess participants' performance. The findings revealed that during the game, participants gradually changed from profit-oriented self-interest strategies to altruistic strategies based on social public benefit. Furthermore, after playing Water Ark, participants' COSK, RWRE, VPB, and EaNT were found to have improved substantially. Thus, Water Ark is believed to be a useful tool for assisting WRA education.
\end{abstract}

Keywords: water resources adaptation; issue-situation-based learning; socio-scientific board game; systemic learning environment

\section{Introduction}

The primary purpose of water resource adaptation (WRA) is to ensure water sustainability; however, WRA is difficult to learn because its content consists of complex and systematic knowledge. Therefore, how to improve the public's knowledge and ability to adapt water resources (WRs) as well as generate awareness of responsibility and willingness to do so are challenge issues. Board games are believed to be effective at assisting WRA learning because they feature role-play simulation, goal orientation, system feedback, and autonomous operation, and can create a systematic learning environment. Using WRA as a background, this study designed an issue-situation-based board game called Water Ark. Playing Water Ark is expected to enhance participants' understanding of WRA concepts as well as their willingness to act upon them. 


\subsection{WRA Education}

Climate change has seriously threatened the supply and consumption of WRs. Adaptation and mitigation are two mainstream action strategies considered as response strategies to climate change. To ensure water sustainability, water resource adaptation (WRA) is considered a critical topic for humans today [1]. WRA refers to how people use various methods and strategies to solve WR problems under the influence of climate change to achieve sustainable WR use. Improving the public's knowledge and WRA ability $[2,3]$ through WRA education has become a vital topic in environmental education. WRA is a multidisciplinary environmental issue involving at least three system, namely nature, society, and the economy. Therefore, the goals of WRA education include but are not limited to assisting learners with their cross-oriented system knowledge (COSK), responsibility for WR environment (RWRE) [4], value of public benefits (VPB) and empathy and negotiating thinking (EaNT) [5].

1. COSK: This is a complete knowledge base for WRA, including aspects such as the prolonged maintenance of WRs, WR management (provision and demand), water footprints [2,6] and the effects of social and economic operations on WRs [7]. These aspects affect each other and each has numerous correlated factors. If learners understand the relationship between these factors and possess COSK, they should have a more comprehensive understanding of WR problems [4].

2. RWRE: Because responsibilities affect the public's willingness to actively participate in environmental issues [8], fostering a sense of responsibility for the environment has always been a priority of environmental education.

3. VPB: WRA involves public benefits. If members of the public only care about themselves and ignore public benefits, this may invalidate the promotion of related topics and even prompt negative risks $[9,10]$. Hence, cultivating learners' VPB is essential for the study of WR problems.

4. EaNT: Decision-making in WRA should consider different opinions because the problem of water sustainability involves a variety of social groups [5]. Showing empathy in the process of communication and negotiation can easily produce an effective solution [11,12].

\subsection{Board Games' Assistance in WR Education}

Achieving the aforementioned four WRA education goals through conventional formal education is relatively difficult, which is mainly because they do not only concern memorizing knowledge but also involve high-level cognitive abilities and interpersonal interactions (i.e., systematic knowledge involves dynamic correlation between complex subsystems, which is difficult to understand and construct $[13,14])$. Members of the public are generally unaware they have responsibility for the environment, thereby making it difficult to promote positive attitudes toward environment $[10,15]$. Fostering willingness to negotiate empathetically with others is difficult [16].

Board games may be an appropriate learning tool to assist WRA education. The characteristics of board games include players playing face-to-face and employing accessories/rules to achieve the game's goal [17]. Studies have indicated that board games are useful for acquiring scientific knowledge [18-20]. For example, Arslan, Moseley and Cigdemoglu (2011) designed a marine-themed board game to help players recognize marine life and environments through a question-and-answer method [21]. Furthermore, Eisenack (2013) developed a board game called Keep Cool; the game teaches players that an increase in the number of factories will lead to an increase in greenhouse gases and environmental damage [18]. Moreover, Peppler, Danish, and Phelps (2013) designed a board game that included interactions between players. Through discussions, learners come to understand the effects ofbees and their cooperative behavior on the environment [22].

According to previous literature, educational board game developers have emphasized knowledge transmission but rarely utilized board game designs to enhance learners' high-level abilities. The board games possess the following features simultaneously: role-play simulations, goal orientation, procedural rules, feedback mechanisms, player interactions, and repeated process rounds. These 
features have been reported the positive effects on enhancing high-level cognitive and interpersonal interactions $[23,24]$. Thus the board games should effectively assist players in learning about WR-related topics.

1. Role-play simulations: Situational and experiential learning are considered effective learning methods because participants can obtain actual experience through the role-play simulation. In a board game, participants are assigned a role from a real or virtual world, and then a context that fits the learning goals is constructed. The participants are integrated into an environment in which the character is located to achieve a goal or solve a problem $[25,26]$. This will help to achieve teaching goals [27].

2. Goal orientation: When a game sets a specific goal, participants will actively explore and learn the game principles to solve the problems they encounter because they wish to achieve the goal. During this process, the participants internalize experience gained in the game into their own cognitive structure $[24,28,29]$. In the future, when the participants encounter similar problems or situations in their daily life, they will be able to utilize this experience.

3. Procedural rules: Games often contain multiple process rounds, which contain various situations and pending issues. Through the appropriate design of rules, a complex concept can be simplified and segregated into different process rounds and finally integrated through game rules. Such a design will guide participants in learning integrative concepts through the game rules $[23,30,31]$.

4. Feedback mechanisms: Each process rule in a board game has a corresponding feedback mechanism to reflect the results produced by the participants after inputting actions. In a general learning environment, it is difficult for participants to immediately obtain feedback after decision-making. However, they can obtain feedback on the decisions they make after a few rounds, and then adjust their decisions and actions based on the feedback to obtain more positive feedback. Such a speedy feedback mechanism will help participants actually experience their own decisions and environmental impacts in a short time [32,33].

5. Player interactions: Interaction is crucial for training empathy, communication, and coordination. Through the game rules set in a board game, participants are required to interact and coordinate with others to solve problems and achieve the game goal. Under such an interactive process, empathy and communication skills can be trained [34-36].

6. Repeated process rounds: Within the game time of a board game, participants usually go through several repeated process rounds until the game is over. During this process, the participants' memory can be enhanced by repetition of retrieval and storage. In addition, the process of repeatedly adjusting decisions allows the participants to have an in-depth understanding of various decisions and their effects. This process will help participants refine their conceptual structure and learn integrative concepts [37].

As previously mentioned, educational board games have in the past focused on how to improve learners' knowledge. To our best knowledge, no systematic reviews have been conducted into game mechanics and their effects on board games. Furthermore, no board game designs have been aimed at improving learners' high-level cognitive skills. Therefore, this study attempted to develop a WRA board game that enhances high-level cognitive abilities, fosters empathy and promotes communication and coordination in learners.

In addition to basing game mechanics on learning objectives, a board game should create a situation that effectively integrates the abovementioned game features to attract learners to willingly and actively participate in the game. Integrating various mechanisms can help learners with systematic induction and thinking [24,32]. To assist learners in self-organizing, criticizing, reflecting, and systematically integrating concepts in a board game, the following situation settings should be considered: (1) the situation should be connected with actual environments; (2) it should create meaningful experiences; (3) participants should be able to design feasible strategies in the game; (4) it should deal with conflicts between different roles; and (5) it should be critically self-reflexive [38,39]. 


\subsection{Research Objectives}

This study aimed to develop an educational board game based on the theme of WRA to enhance the public's knowledge of and ability to adapt water resources. The board game design followed the plan set out in Table 1. The objectives of the study were as follows:

1. To develop a WRA educational board game.

2. To evaluate participants' performance in COSK, RWRE, VPB, and EaNT after playing the game.

Table 1. Water Ark's planning steps and design contents.

\begin{tabular}{cc}
\hline Planning Steps & Design Contents \\
\hline Learning Objectives & Participants: Members of the public with above high school-level education. \\
\hline Issue Contents & Knowledge of and capacity for WRA: COSK, RWRE, VPB, and EaNT. \\
\hline Structural Rules & $\begin{array}{c}\text { Role-play simulation: Government, industrial sector, agricultural sector, and public guild. } \\
\text { Goal orientation: Obtain the highest score. } \\
\text { Procedural rules: Simulate social operations related to WRs. Participants use various } \\
\text { strategies to achieve the highest scores and small goals in each situation. }\end{array}$ \\
\hline System Environment & $\begin{array}{c}\text { Feedback mechanisms: Climate mechanism, social system, economic system and model, } \\
\text { technology mechanism, and public health mechanism. } \\
\text { Player interaction: Participants are divided into groups and require teamwork to win. } \\
\text { The game is designed to be open to social and interactive environments. }\end{array}$ \\
\hline
\end{tabular}

\section{Materials}

To achieve educational effectiveness, the design of Water Ark was divided into four steps: setting learning objectives, confirming issue contents, formulating structural game rules, and constructing system environment $[30,33]$. Table 1 presents the four planning steps and contents of Water Ark.

\subsection{Water Ark's Learning Objective Setting}

Water Ark's learning objective is to cultivate the public's knowledge and abilities concerning WRA. Because participants' education level can influence their decision-making behaviors when solving complex problems, this study selected members of the public with high school and above education levels as the participants.

\subsection{Scope of the Study on WRA}

To achieve the goal of WRA education, this study designed a learning scope that consisted of COSK, RWRE, VPB and EaNT to cultivate participants, as shown in Table 2.

Table 2. Water Ark's learning objectives and contents.

\begin{tabular}{cc}
\hline Learning Objectives & Contents \\
\hline COSK & $\begin{array}{c}\text { Understanding the prolonged maintenance of WRs, WR management (provision } \\
\text { and demand), water footprints, and the effects of society and economy on WRs } \\
\text { (Figure 1). }\end{array}$ \\
\hline RWRE & Understanding the concept of WR systems and having the responsibility and \\
willingness to act on WRA.
\end{tabular}




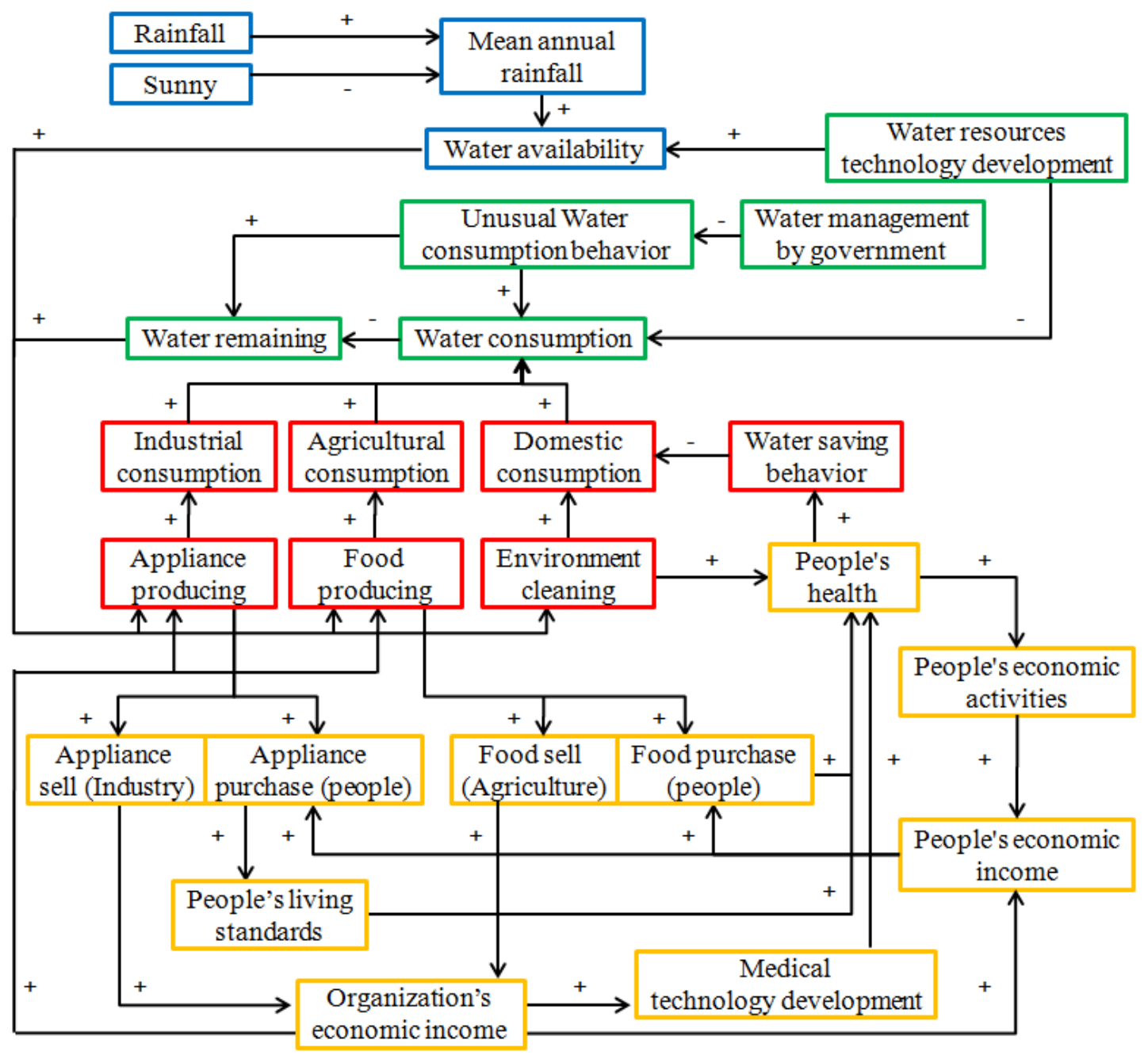

Figure 1. Relevant conceptual structure of water resource adaptation (WRA) in Water Ark. Notes: Each box represents a factor related to WRA, the arrows represent possible response relationships (positive or negative) between two factors, and the factors at the arrow tails affect the factors at the arrow heads. For example, higher mean annual rainfall indicates that more water is available. In this figure, the blue boxes are water resource (WRs) maintenance; the green boxes are the supply of WRs, including the use of WRs and water rights management; the red boxes are the consumption of WRs; and the orange boxes are the effect of society and the economy on WRs.

\subsection{Game Rules of Water Ark}

The first step in Water Ark's planning was setting up three features: role simulation, goal orientation, and procedural rules. Prioritizing these features allows for clarity of the game structure, which assists in planning subsequent game events [24,40] and creating autonomous learning environments [38,39]. Table 3 presents the setting of game rules for Water Ark. The game scores are aggregated by the organization's cash, available water resources, implementation of water resource adaptation measures, and public health indicators. If public health drops below a certain level, the game is terminated.

The second step in Water Ark's planning was to design two features, the feedback mechanism and player interaction, as well as create various game settings [12] (Table 5). In this process, they are expected to be able to establish COSK, trigger RWRE, and generate VPB. Water Ark is a game designed for open social interaction, where participants can discuss and negotiate national WR planning with each other. 
Table 3. Water Ark's setting of game rules.

\begin{tabular}{|c|c|c|c|}
\hline Features & Content Setting & Learning Objectives & Situation Setting \\
\hline $\begin{array}{l}\text { Role-play } \\
\text { Simulation }\end{array}$ & $\begin{array}{l}\text { Role setting: Government, industrial } \\
\text { sector, agricultural sector, and public guild } \\
\text { (Figure 2). } \\
\text { Description: Each group plays a } \\
\text { WRA-related organization in real life that } \\
\text { has cooperation and conflicts in their } \\
\text { standpoints. These organizations have } \\
\text { different operational objectives. }\end{array}$ & $\begin{array}{ll}\bullet & \mathrm{RWRE} \\
\mathrm{EaNT}\end{array}$ & $\begin{array}{l}\text { Connect with the environment } \\
\text { Create meaning experientially } \\
\text { Deal with conflicts }\end{array}$ \\
\hline Goal Orientation & $\begin{array}{l}\text { Setting: Each organization competes with } \\
\text { each other to strive for the highest score } \\
\text { and win. The scores are calculated } \\
\text { according to players' balances, remaining } \\
\text { WRs, scores for implementing WRA } \\
\text { measures, and national survival scores. }\end{array}$ & $\begin{array}{ll} & \text { COSK } \\
\text { RWRE } \\
\text { VPB } \\
\text { EaNT }\end{array}$ & $\begin{array}{l}\text { Connect with the environment } \\
\text { Deal with conflicts }\end{array}$ \\
\hline Procedural Rules & $\begin{array}{l}\text { Setting: Refer to the real operating mode of } \\
\text { society and establish seven simulated } \\
\text { real-world scenarios (Table } 4 \text { ). } \\
\text { Description: Simulate real operating rules } \\
\text { of society, help participants learn the } \\
\text { concepts of WR systems, and generate } \\
\text { positive attitudes in various situations. }\end{array}$ & $\begin{array}{ll} & \text { COSK } \\
\text { RWRE } \\
\text { VPB } \\
\text { EaNT }\end{array}$ & $\begin{array}{l}\text { Connect with the environment } \\
\text { Create meaning experientially } \\
\text { Design feasible strategies } \\
\text { Deal with conflicts } \\
\text { Be critically self-reflexive }\end{array}$ \\
\hline
\end{tabular}
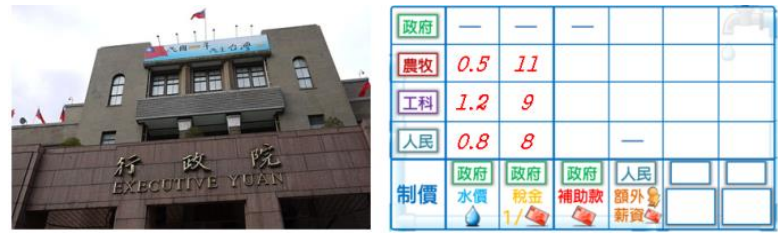

(a)

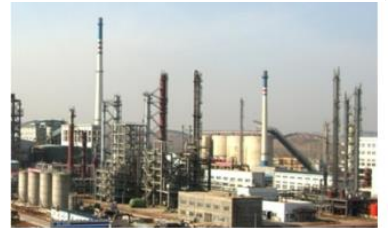

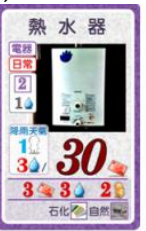

(c)

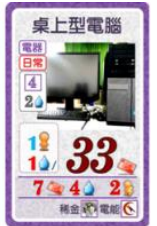

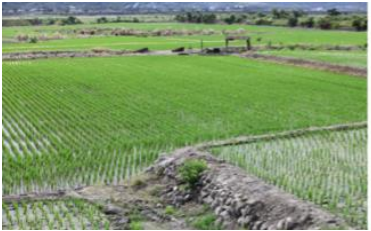

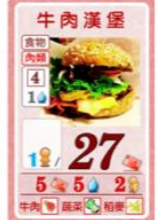

(b)
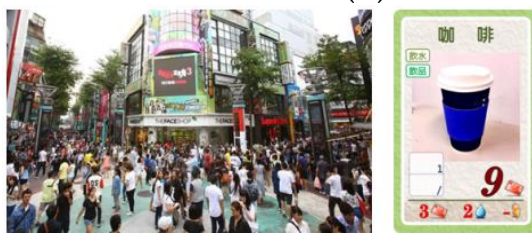

(d)

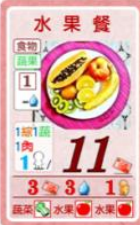

Figure 2. In Water Ark, participants can choose the organization of which they wish to play the role. Notes: Each organization has different goals: (a) Government: responsible for formulating social and economic systems; (b) Agricultural sector: responsible for food production; (c) Industrial sector: responsible for electrical equipment production; and (d) Public guild: responsible for providing clean, usable, and drinkable water for the public.

Table 4. Water Ark's game events and corresponding learning objectives.

\begin{tabular}{|c|c|c|c|c|}
\hline \multirow{2}{*}{ Water Ark's Game Events } & \multicolumn{4}{|c|}{ Learning Objectives Related to Each Event } \\
\hline & COSK & RWRE & VPB & EaNT \\
\hline 1. Climate Influences & $\mathrm{v}$ & $\mathrm{v}$ & & \\
\hline 2. System Formulation & $\mathrm{v}$ & & & $\mathrm{v}$ \\
\hline 3. Resource Acquisition & $\mathrm{v}$ & $\mathrm{v}$ & & $\mathrm{v}$ \\
\hline 4. Production of Products & $\mathrm{v}$ & $\mathrm{v}$ & & $\mathrm{v}$ \\
\hline 5. Product Trading & $\mathrm{v}$ & & & $\mathrm{v}$ \\
\hline 6. Technology Development & $\mathrm{v}$ & & & \\
\hline 7. National Survival ${ }^{1}$ & $\mathrm{v}$ & & $\mathrm{v}$ & $\mathrm{v}$ \\
\hline
\end{tabular}

${ }^{1}$ At the end of each round, the instructor will examine health indicators of the public. Public health indicators are determined by the organizations' provision of adequate food, drinking water, and clean water. Therefore, organizations should consider how to maintain public health while simultaneously improving their scores. 
Table 5. Water Ark's system.

\begin{tabular}{|c|c|c|}
\hline Game Events & Feedback Mechanism and Player Interaction & Situation Setting \\
\hline Climate Influences & $\begin{array}{l}\text { Feedback mechanism: Participants draw a climate card and } \\
\text { throw a die to obtain the mean annual rainfall under the } \\
\text { influence of weather. This mechanism presents weather is an } \\
\text { uncontrollable feature. }\end{array}$ & $\begin{array}{l}\text { Reflecting the conceptual relationship: Climate } \\
\text { types and amount of WRs }\end{array}$ \\
\hline $\begin{array}{c}\text { System } \\
\text { Formulation }\end{array}$ & $\begin{array}{l}\text { Feedback mechanism: Organizations conduct open and } \\
\text { private negotiations with the government, and the government } \\
\text { sets water prices and taxes for this round. Subsequently, the } \\
\text { government allocates the WRs required by each organization } \\
\text { based on negotiations with all organizations. } \\
\text { Player interaction: The allocation of WRs and price setting are } \\
\text { dominated by the government through the negotiation. }\end{array}$ & $\begin{array}{c}\text { Reflecting the conceptual relationship: WRs and } \\
\text { economics, and policy and social operations } \\
\text { Organizational topics: Management and economics } \\
\text { Negotiating opportunity: When setting and } \\
\text { confirming prices }\end{array}$ \\
\hline $\begin{array}{l}\text { Resource } \\
\text { Acquisition }\end{array}$ & $\begin{array}{l}\text { Feedback mechanism: All organizations conduct open and } \\
\text { private negotiations with the government to obtain more WRs } \\
\text { at lower prices. } \\
\text { Player interaction: All organizations participate to acquire the } \\
\text { required resources. }\end{array}$ & $\begin{array}{l}\text { Organizational topics: Resource management } \\
\text { Negotiating opportunity: When requesting } \\
\text { for resources }\end{array}$ \\
\hline $\begin{array}{l}\text { Production of } \\
\text { Products }\end{array}$ & $\begin{array}{c}\text { Feedback mechanism: Organizations plan the products they } \\
\text { expect to produce based on human resources, WRs, production } \\
\text { costs, and product prices. } \\
\text { Player interaction: Production by the industrial sector, } \\
\text { agricultural sector, and public guild. }\end{array}$ & $\begin{array}{l}\text { Reflecting the conceptual relationship: Water } \\
\text { footprints, and economic and labor costs } \\
\text { Organizational topics: Planning and development } \\
\text { Effect of WRs: The effect of products produced on } \\
\text { the public } \\
\text { Negotiating opportunity: During } \\
\text { production planning }\end{array}$ \\
\hline $\begin{array}{l}\text { Trading of } \\
\text { Products }\end{array}$ & $\begin{array}{l}\text { Feedback mechanism: Earn products or money through } \\
\text { product trading. } \\
\text { Player interaction: All organizations participate in trading, } \\
\text { and products and money flow between organizations. }\end{array}$ & $\begin{array}{c}\text { Reflecting the conceptual relationship: Money, } \\
\text { price, and product } \\
\text { Organizational topics: Trade and benefits } \\
\text { Negotiating opportunity: When buying and selling } \\
\text { products, and performing payment }\end{array}$ \\
\hline $\begin{array}{l}\text { Technology } \\
\text { Development }\end{array}$ & $\begin{array}{l}\text { Feedback mechanism: Improving WR technology can } \\
\text { improve water utilization. Furthermore, improving medical } \\
\text { technology can improve the quality of WRs. When players } \\
\text { implement the abovementioned game strategies, they must } \\
\text { pay extra money and manpower, and the money will not be } \\
\text { returned. This mechanism is an altruistic act. } \\
\text { Player interaction: Discussion between the government and } \\
\text { other organizations on whether to share the costs of research } \\
\text { and development of WRs or the promotion of medical care. }\end{array}$ & $\begin{array}{c}\text { Reflecting the conceptual relationship: Water } \\
\text { footprints, and technology cost and effect } \\
\text { Organizational topics: The effect of technology on } \\
\text { national development } \\
\text { Negotiating opportunity: When } \\
\text { developing technology }\end{array}$ \\
\hline National Survival & $\begin{array}{c}\text { Feedback mechanism: Public health is one of the indicators } \\
\text { for scoring in the game. Low health indicates higher labor } \\
\text { costs. The game will be terminated when the health indicator } \\
\text { is below a certain level. } \\
\text { Player interaction: All organizations participate in and } \\
\text { negotiate how to maintain public health. }\end{array}$ & $\begin{array}{l}\text { Reflecting the conceptual relationship: Public } \\
\text { demand for food and water. } \\
\text { Organizational topics: Organizational responsibility } \\
\text { to the public and organizational score development } \\
\text { Effect of WRs: Effect of WRs on public health }\end{array}$ \\
\hline
\end{tabular}

\subsection{Implementation of Water Ark}

Water Ark is designed to guide participants in experiencing the roles of organizations and the government in WRs. When faced with WR shortages, participants will shift from economically destructive competition to environmentally friendly cooperative behavior. Through joint consultation, changing decisions and actions in the game will result in increased income and WRs (positive feedback) compared with the beginning of the game. Learning VPB and EaNT can be promoted when the participants realize the importance of public benefits in the game [4]. The game process is shown in Figure 3; the participants play the role of the government, industrial sector, agricultural sector, and public guild. In each round, participants face seven events in sequence: climate influences, system formulation, resource acquisition, production of products, product trading, technology development, and national survival. In each situation of each round, participants can implement strategies and interact with each other to gain more benefits. At the end of the game, the score is determined by the available cash and WRs as well as the adjustment measures performed. Participants will continue to attempt feasible strategies for decision-making in each round. This process is expected to refine the knowledge and ability of the WR adaptation of the participants [37] (Figures 3 and 4). 


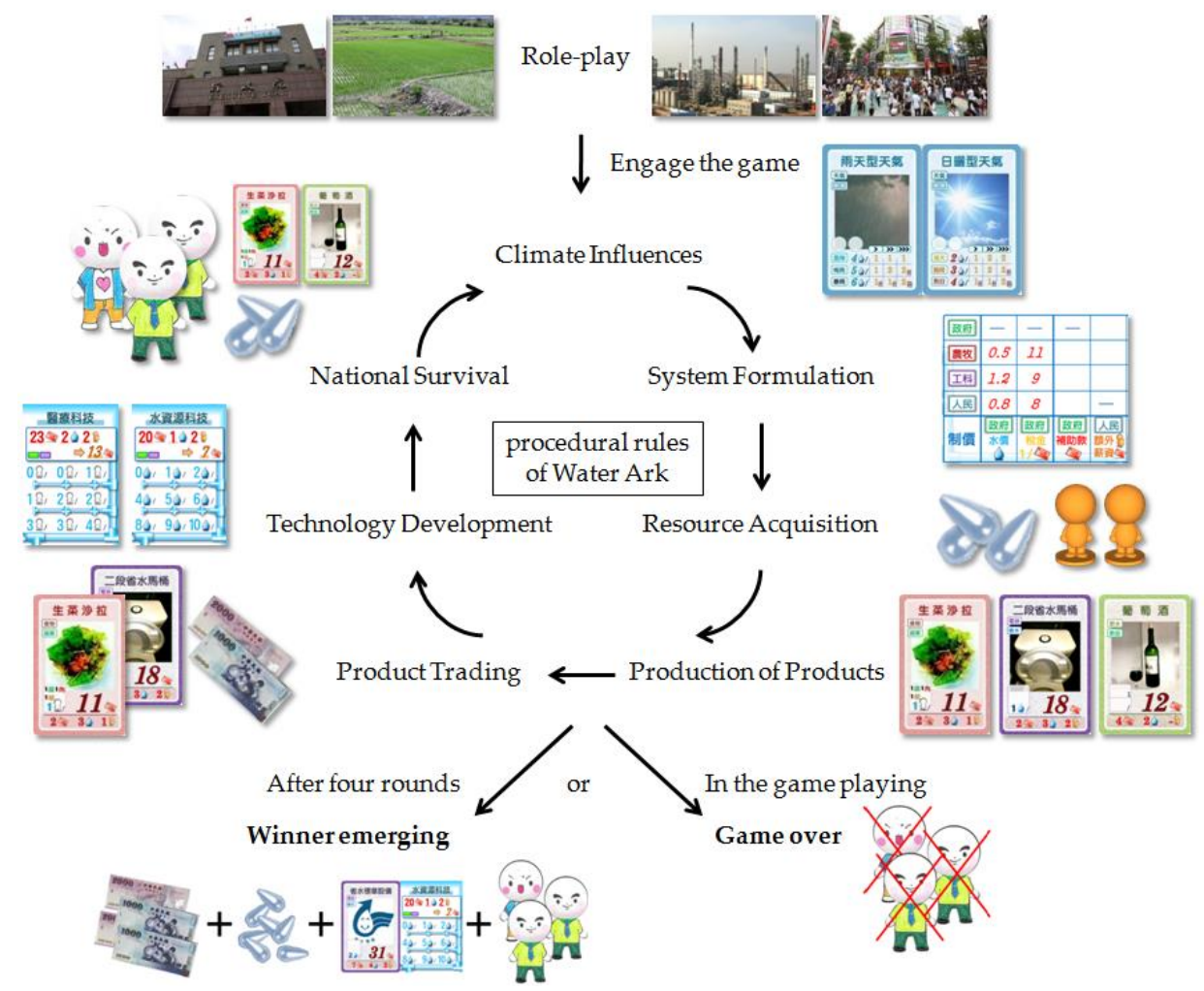

Figure 3. Illustration of Water Ark's procedural rules. Notes: At the beginning of the game, participants are required to choose one of the following roles to play: the government, industrial sector, agricultural sector, or public guild. Then participants face seven events in each round until game ended.

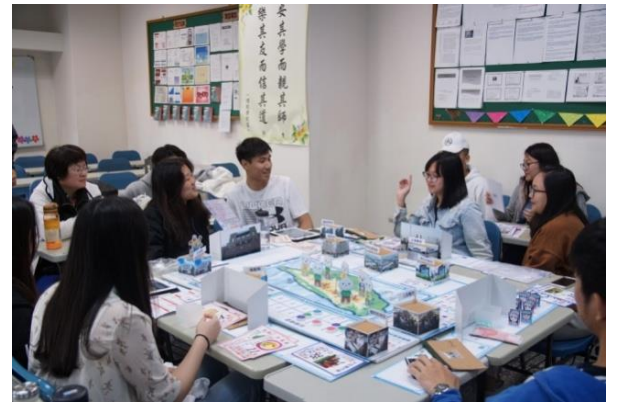

(a)

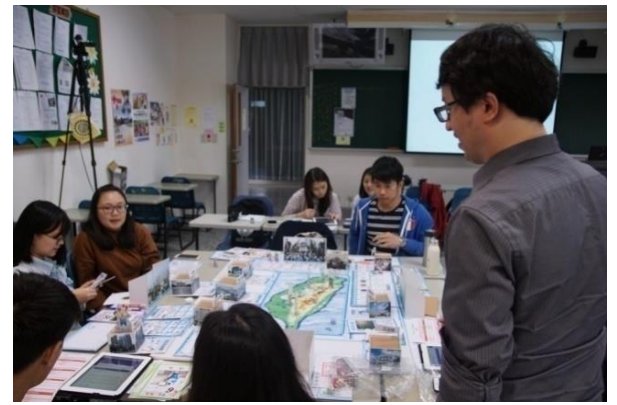

(c)

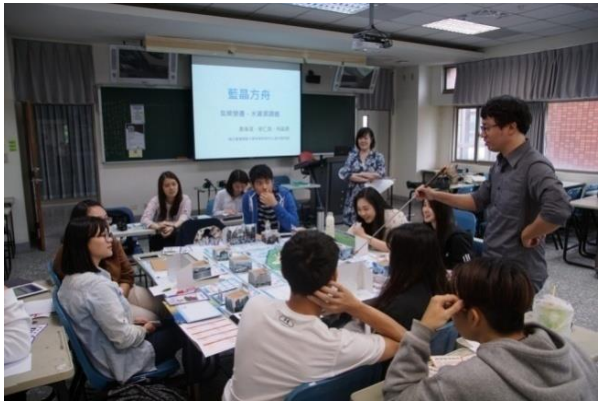

(b)

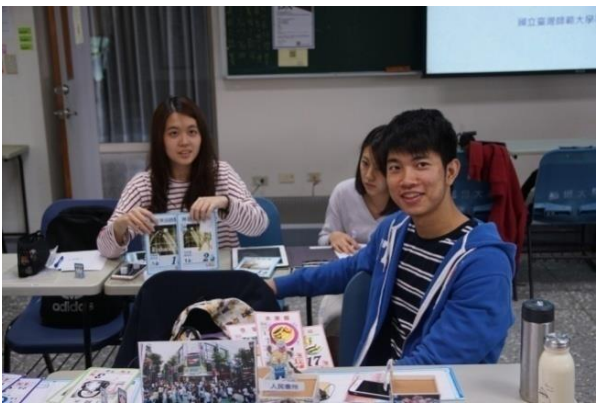

(d)

Figure 4. Implementation of Water Ark. Notes: (a) System formulation: The government (left) formulates economic systems and represents the industrial sector (middle) to express their views on water allocation. (b) Resource acquisition: Each organization requests the required water resources from the government (right), and the government allocates resources according to their needs. (c) Product trading: Public guild (middle) and industrial sector (left) are trading products. (d) National survival: The public guild player sums up the maintenance conditions for public health. 


\section{Methods}

\subsection{Instruments}

This study developed three instruments to evaluate different aspects of participants' performance. The COSK test has an open-ended question, which was used to assess participants' understanding of WRA-related concepts. In the test, participants were asked to state the relationships of factors in the WRA conceptual net. The WRA conceptual net cover four issues: understanding the prolonged maintenance of WRs, WR management, water footprints, and the effects of society and economy on WRs (as shown in Figure 1). Students would get one-point if they correctly response each relationship in this section. Two experienced teachers were asked to grade students' answers following the standard answers and scoring criteria we provided.

The second instrument, a 25-question RWRE questionnaire was developed to evaluate participants' awareness and responsibility for WRA [41]. Example items are "Water resources are highly related to economic development" and "Do you care more about the water resource environment than about work or affordable prices?" This questionnaire employed a five-point Likert scale, and the participants selected the option that best suits his or her feelings from among five options, ranging from strongly agree to agree, neutral, disagree, and strongly disagree.

VPB evaluation was conducted using a game-action questionnaire and game record. The game-action questionnaire asked the participants whether they had implemented the actions they would have taken in real life when implementing public benefits in the board game; for example, "I took action to support the engineering industry to produce water-saving appliances or equipment in the game" and "In the game, I took action to raise objections when an organization exploited water resources without considering the needs of other organizations." If any action was taken, participants filled in "Yes," and if not they filled in "No" for a total of five questions. During the game, participants were asked to record each decision they made at each particular point, state their rationale for making such a decision. At the end of each round, they were also asked to record how many money and WRs they owned, and how many national survival.

Interview: After the game, random sample interviews were conducted with the game participants. During the interview, participants were asked to explain the concepts they had learned in the game and in reality regarding VPB and EaNT. In addition, participants were asked to provide their thoughts after playing the Water Ark board game.

\subsection{Procedural and Statistical Analysis}

This study was conducted in an urban university in Taiwan. Participants were recruited form an "Issues in Environmental Science" course. A total of 21 students, 9 of whom were male, were included. They ranged in age from 18 to 20 years. Note that the small sample size is a major limitation of this study in discussing and generalizing its results. The participants were randomly divided into four groups with three to four participants per group. Each group played the role of one of four organizations (government, industrial sector, agricultural sector, and public guild). The group with highest score won the game. To evaluate the effectiveness of Water Ark, this study employed a preand post-test in the research design. The research process is shown in Table 6.

The data collection and analysis methods employed were as follows: (1) The COSK test and the RWRE questionnaire were administered before and after the game. Paired samples $t$ tests and effect size were used to evaluate participants' learning outcomes. (2) The VPB evaluation is an evaluation of the participants' performance during and after the game. The game-action questionnaire was analyzed using a paired sample $t$-test and effect size, where as the game-performance record presented the results using charts. (3) After the game, five participants were randomly selected as the interviewees. A content analysis method was employed to evaluate the participants' VPB, EaNT, and thoughts after playing Water Ark. The coding numbers for the five participants were AS, IS, PS, GS1 and GS2. 
Table 6. Water Ark's research process.

\begin{tabular}{ccc}
\hline Time & Content & Tool \\
\hline $30 \mathrm{~min}$ & Pre-test & $\begin{array}{c}\text { The COSK test } \\
\text { The RWRE questionnaire }\end{array}$ \\
\hline $150 \mathrm{~min}$ & First game session of Water Ark & $\begin{array}{c}\text { Board game: Water Ark } \\
\text { The VPB evaluation }\end{array}$ \\
\hline $120 \mathrm{~min}$ & Second game session of Water Ark & $\begin{array}{c}\text { Board game: Water Ark } \\
\text { The VPB evaluation }\end{array}$ \\
\hline $30 \mathrm{~min}$ & Post-test & $\begin{array}{c}\text { The COSK test } \\
\text { The RWRE questionnaire } \\
\text { Interview on VPB and EaNT }\end{array}$ \\
\hline
\end{tabular}

\section{Results and Discussion}

\subsection{Students' Cross-OrientedSystem Knowledge Before and After the Test}

Table 7 presents the participants' performance in the COSK test. The post-test results were not statistically superior to the pre-test results $(t(20)=1.43, p=0.16 ; t(20)=1.28, p=0.21)$; however, they achieved a small to medium effect size $(0.31 ; 0.33)$. During the interviews, the participants generally responded that they had learned the relationships between multiple factors through playing Water Ark. Furthermore, they indicated that such an integrated concept is difficult to obtain in conventional learning situations. For instance, the participants came to understand the cross-sectional relationship of climate systems, available water, and the value of WRs (AS, IS), and the system concept, and gained deep impression of water footprints and social operations (GS2).

Table 7. Participants' performance of cross-oriented system knowledge (COSK).

\begin{tabular}{ccccc}
\hline & Variables & Mean (SD) & $\boldsymbol{t}$ & Effect Size \\
\hline \multirow{2}{*}{ entry1 } & WRA knowledge (Post-test) & $13.46(4.03)$ & \multirow{2}{*}{1.43} & \multirow{2}{*}{0.31} \\
& WRA knowledge (Pre-test) & $12.29(3.31)$ & & \multirow{2}{*}{ entry2 } \\
& Cross-oriented knowledge (Post-test) & $4.87(1.87)$ & \multirow{2}{*}{1.28} & \multirow{2}{*}{0.33} \\
& Cross-oriented knowledge (Pre-test) & $4.21(2.18)$ & & \\
\hline
\end{tabular}

The COSK test results did not reveal significant differences may be due to the small samples. In this study, with a rather small sample size, the result of statistical insignificance is more likely to happen. The result of medium effect size may signify the possibility of finding statistical significance of this comparison with a future replication of study with a larger sample size [42,43]. Besides, studies have shown that an open test is more likely to cause test anxiety, resulting in the poor performance of participants. In particular, the pre- and post-test study design may have led to a lack of participants' willingness to respond because both tests were conducted within a short period, which could have resulted in only partial performance being reflected in the test results [44-46].

During the interviews, the participants mentioned the influence of Water Ark's game characteristics on their systematic knowledge acquisition. First, the role simulation mechanism helped them to assimilate into their roles, which contributed to their systematic knowledge acquisition. For example, playing the role of the government will help participants learn to consider the effect of water pricing and taxes on social and economic systems as well as the effect on WRs (GS2). Moreover, participants learn to observe the overall social structure from their roles' perspective during decision-making (PS). Second, this game provided opportunities for practical exploration and practice, wherein participation in the game helped the participants to construct WRA concepts from a system perspective. These concepts include understanding the correlation between WR management and economic development, how to rationally use WRs based on actual needs, and assessing the actual benefits of water use through water footprints and water use efficiency (GS1). Third, the integration of 
complex WR concepts as well as conflicts and partnerships between various roles in society into the board game rules could enhance participants' learning motivation.

\subsection{EnhancingResponsibility for the WREnvironment}

Table 8 shows that after participating in Water Ark, participants' awareness of and responsibility for the WR environment notably improved compared with before participating $(t(20)=2.54, p<0.05$; $t(20)=5.99, p<0.01)$, with large effect size $(0.49,0.98)$. During the interviews, participants also revealed that after participating, they realized that WR issues contain both scientific and social factors and WRs often directly or indirectly affect various industries (GS1, GS2, AS, IS). Furthermore, they realized the importance and necessity of WRA, how WR management affects organizations and daily life, and how the misuse of WRs eventually affects people's survival (GS2, AS).

Table 8. Participants' performance of responsibility for the WR environment (RWRE).

\begin{tabular}{ccccc}
\hline & Variables & Mean (SD) & $t$ & Effect Size \\
\hline \multirow{2}{*}{ entry1 } & Awareness of the WR environment (Post-test) & $4.34(0.34)$ & \multirow{2}{*}{$2.54 *$} & \multirow{2}{*}{0.49} \\
entry2 & Awareness of the WR environment (Pre-test) & $4.17(0.36)$ & & \\
& Responsibility for the WR environment (Post-test) & $3.99(0.44)$ & \multirow{2}{*}{$5.99 * *$} & 0.98 \\
\hline
\end{tabular}

$$
{ }^{*} p<0.05,{ }^{* *} p<0.01 \text {. }
$$

Water Ark could motivate participants to be responsible for the WR environment because it simulates a social operation environment. Three of the participants, GS2, IS, and PS, indicated the following:

GS2: Through this game, I realized that everyone will be affected by WRs. Therefore, instead of being passive in the face of WR problems, we should actively solve them.

IS: I began to be concerned about water sustainability and think about possible solutions through the role-play. I have never cared about water problems in the past and thought they had nothing to do with me. Now, I am beginning to reflect on the meaning behind each type of water use behavior as well as establish correct behaviors!

PS: I have gained valuable ideas through this game and will apply the concepts I have learned in future actions. Regardless of whether we are playing the game or are in reality, we must take responsibility for water sustainability for the sake of environmental sustainability and social development.

In the simulated environment in Water Ark, participants experienced the WR operating environment and implemented WRA behaviors. Such an environment motivated them to be responsible, and furthermore, they believed that they should apply the concepts they had learned in the board game to real life. The evidence suggests that Water Ark should be able to achieve the effects of transfer of learning and play a role in water conservation education.

\subsection{Students' Learning of the Value of Public Benefit}

Water Ark's educational goals reflect a focus on public benefits and sustainability. In the two game sessions, the participants acted for the sake of public benefit and WR sustainability, supported the same actions of other organizations, and actively prevented water wastage or unrestricted water intake by other organizations.

According to the $t$-test results, the proportions of public benefit actions taken by the participants in the post-test was $66 \%$, which is significantly higher than in the pre-test $(t(20)=4.05, p<0.01)$ with a large effect size (Table 9). It is also noted that the pre- and post-test coefficients of effect size is higher than general environmental education teaching method (approximately 0.5) [47]. The results of this 
study showed that Water Ark should be able to effective, with a considerable effect on participants' willingness to perform public-benefit actions.

Table 9. Participants' performance of Value of Public Benefit (VPB).

\begin{tabular}{ccccc}
\hline & Variables & Mean (SD) & $t$ & Effect Size \\
\hline \multirow{2}{*}{ entry1 } & Actions taken in the game (Post-test) & $3.31(1.04)$ & \multirow{2}{*}{$4.05^{* *}$} & \multirow{2}{*}{1.10} \\
& Actions taken in the game (Pre-test) & $2.14(1.08)$ & & \\
\hline &
\end{tabular}

The records in the game history reflected participants' decisions and results. Table 10 and Figure 5 show that after gaining experience from the first session, the participants were willing to act altruistically from the perspective of public benefit when participating in the second session. From the interviews, this result was attributed to the setting of the game's feedback mechanism. Most participants expressed that the feedback mechanism often prompted them to reflect and adjust their problem-solving strategies.

Table 10. Overall scores for each group at the end of the game (after two sessions).

\begin{tabular}{|c|c|c|c|c|c|c|}
\hline \multirow[b]{2}{*}{ Session } & \multirow[b]{2}{*}{ Organizations } & \multicolumn{4}{|c|}{ Orientation } & \multirow{2}{*}{$\begin{array}{c}\text { Overall } \\
\text { Scores }\end{array}$} \\
\hline & & Economics & $\begin{array}{c}\text { Water } \\
\text { Resources }\end{array}$ & $\begin{array}{l}\text { Sustainability } \\
\text { Measures }\end{array}$ & $\begin{array}{l}\text { National } \\
\text { Survival }\end{array}$ & \\
\hline \multirow{5}{*}{ First } & Government & 3 & 0 & 6 & 15 & 24 \\
\hline & Industrial & -5 & 2 & 6 & 15 & 18 \\
\hline & Agricultural & -2 & 0 & 4 & 15 & 17 \\
\hline & Public Guild & -7 & 4 & 4 & 15 & 16 \\
\hline & Average & -2.75 & 1.5 & 5 & 15 & 18.75 \\
\hline \multirow{5}{*}{ Second } & Government & 32 & 4 & 2 & 24 & 62 \\
\hline & Industrial & 44 & 4 & 6 & 24 & 78 \\
\hline & Agricultural & 30 & 2 & 8 & 24 & 64 \\
\hline & Public Guild & 23 & 0 & 10 & 24 & 57 \\
\hline & Average & 32.25 & 2.5 & 6.5 & 24 & 65.25 \\
\hline
\end{tabular}

GS1: Declining public health greatly affected my decision-making directions. Initially, my strategy was to prioritize making money but this gradually changed to aiming for mutual benefits.

AS: After the first round, public health declined rapidly. This phenomenon caused all organizations to stop making their own profit a priority. They began to negotiate for the sake of the entire country. We finally succeeded in raising public health.

IS: When public health declined, I realized that we should value WRs and use them properly. I also realized that maintaining the health and safety of the public is the basis for both mutual benefits.

PS: When people were dying, we abandoned our interests and achievements and worked together for the sake of public health. We noticed that we would make more money and benefits after raising public health.

Interview outcomes showed that participants learned to perform altruistic behavior for the public's benefit (all organizations, the public) in the later stages of the game. For example:

GS2: The main goal of the government is to benefit the public, not to benefit themselves or a specific organization.

IS: Although it cost much money to work with the government to develop technology that could improve the public's health, it seemed that the benefits tended to increase after a few rounds. 


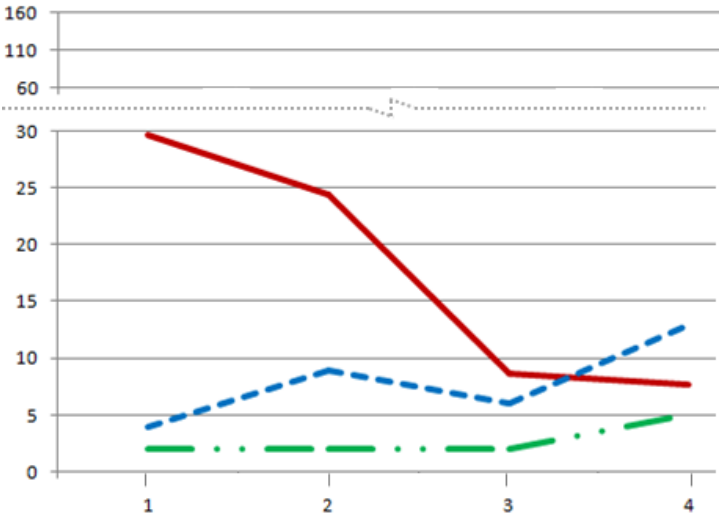

(a)

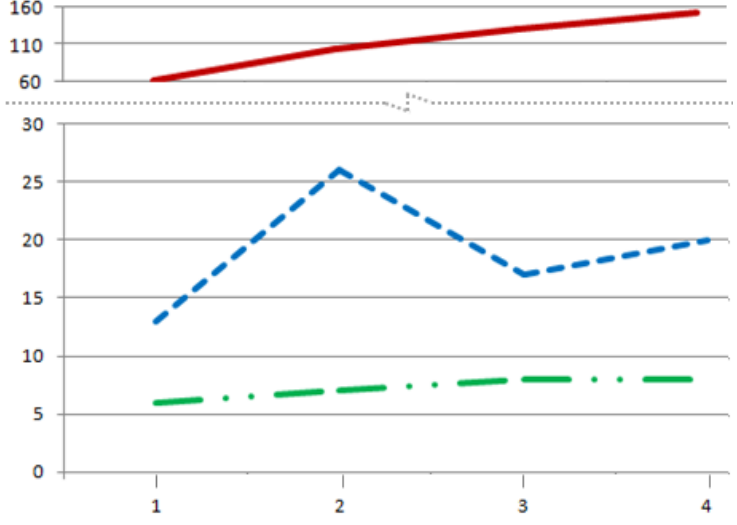

(b)

Figure 5. Game-performance record: the x-axis is the number of rounds and the $y$-axis is the amount. Notes: Red solid lines represent the total amount of money of all organizations; blue dotted lines represent the total amount of remaining water of all organizations; and green solid-dotted lines represent the public health indicator. (a) The performance of each round in the first game session. (b) The performance of each round in the second game session. The participants did not consider the public's needs, causing public health to decline in the first round of the first session. As public health rose, reservoirs' water storage capacities also gradually increased. In the second session, the public health indicator, stock of water resources, and the country's overall economy were in a gradual upward trend.

Participants' game experience and interactions with others helped them to reflect on social phenomena in daily life. For instance, organizations should coordinate and communicate actively and achieve mutual benefit when facing social problems in real life (GS2, AS). Public benefits should be considered in addition to organizations' own interests to gain more profit and make progress in social development (PS). In addition, participants believed that they could implement concepts learned from the game in future actions and ideas (PS). In Water Ark, we designed an appropriate environment for player interaction, allowing participants to be motivated and learn from each other as well as trigger favorable learning transfer [34].

\subsection{Acquired of the Empathy and Negotiating Thinking}

In their interview responses, the participants mentioned that they had learned to consider problems from the positions and characteristics of other organizations in the game. The results revealed that after the game, participants realized that to solve problems effectively when implementing WRA actions, they should put themselves in the position of different organizations, treat each other with empathy, communicate, and negotiate.

GS1: Through negotiations, organizations abandoned their own interests and planned WR utilization policies together, resulting in raised income for everyone.

GS2: We decided to raise the water prices of the industrial sector because it made a much money. However, the industrial sector participants expressed strong objections and put meat a loss. After consideration, I realized that a lack of communication and negotiation caused those participants to become angry because we only made decisions based on what we saw on the surface.

AS: Industrial organizations protested to the government that they had no money left and donated their remaining water to other organizations. This action inspired me and I proposed opinions on the government's taxation with the hope of benefiting everyone.

PS: We noticed that the agricultural sector lacked funds to purchase equipment. Therefore, we spent our money to purchase water-saving equipment for them. 
GS2: When I recalled the game, objections by the industrial sector against us prompted me to reflect that we should be able to reach a consensus more effectively with sufficient communication.

IS: I noticed that learning how to manage, negotiate, and resolve conflicts was crucial. From the perspective of business operators, lacking cooperation to resolve conflicts and using resources self-sufficiently will lead to losses for both parties.

In addition, the participants expressed that through Water Ark's simulated environment, role-playing, and face-to-face participation, they could deeply understand the WR environment and implement problem-solving actions, which they had never experienced in their regular curriculum.

GS2: My group members raised their own thoughts and opinions, and communicated and cooperated well with each other.

PS: Participants could recognize the positions of different roles through playing the game, and were able to make decisions from the perspective of other roles.

IS: Through the interactive negotiation and decision-making process, I experienced the social operation of WRs.

Water Ark integrates features from numerous other board games and creates a flexible discussion space that matches the openness and multiples views of social science topics [48]. Simultaneously, the participants could continually adjust their solutions in each repeated round to achieve deliberate practice [49].

\subsection{Correlations between Personal Attitude and Actions of VPB Taken in the Game}

Since personal characteristics, such as gender, personal attitude and belief, can have a significant impact on a person's perception and behavior [50,51]. This study attempted to explore the relationships between personal characteristics before game play and public benefit actions during the game. No significant associations were seen between the gender and the public benefit actions. As shown in Table 11, participants' actions of VPB taken in the game was positively associated with responsibility for the WR environment $(r=0.51$, large effect size $)$ and awareness of the WR environment $(r=0.26$, medium effect size).

Table 11. Intercorrelations between personal attitude and actions of VPB taken in the game.

\begin{tabular}{cccc}
\hline Variables & $\mathbf{1}$ & $\mathbf{2}$ & $\mathbf{3}$ \\
\hline 1. Awareness of the WR environment (pre-test) & 1 & - & - \\
2. Responsibility for the WR environment (pre-test) & 0.56 & 1 & - \\
3. Actions of VPB taken in the game & 0.51 & 0.26 & 1 \\
\hline
\end{tabular}

The results indicated that personal attitude were associated with actions of VPB taken in the game. This could be explained by the theory of planning behavior (TPB) by Ajzen (1985), which predicts the link among attitude, behavioral intention, and behavior [52]. Thus, the relatively high public benefit actions during the game can be attributed to positive attitudes toward the responsibility for the WR environment. Therefore, how to improve learners' attitude toward specific topic can be the critical component in the success of the board game in assisting learning.

\section{Conclusions and Implications}

The features of multiple board games were integrated into Water Ark through setting the game environment, and water conservation problems were incorporated into the game, allowing participants to learn through their participating in the game. The results from this study, though seems to be limited by its small sample size, also provided some valued implications for future works. The results 
revealed that Water Ark could enhance participants' knowledge and ability in WRA issues as follows: (1) Participants could understand COSK because the game goals and procedural rules presented knowledge about WRA; (2) Water Ark helped participants to assimilate into the game and improved their responsibility for RWRE because it simulated real environments and role-play; (3) Water Ark's feedback mechanism helped participants to generate VPB; and (4) participants had to communicate and negotiate to solve problems, which aroused participants' EaNT.

In assessing participants' performance, their decisions and outcomes in the game process (every round) were recorded as one of the evaluation strategies. In addition, participants' reflections in the game-performance record can be used as a tool for promoting participants' meta-cognition. After the first session of Water Ark's implementation, the author provided game records to the participants and asked them to express their thoughts. The participants recalled their experience (success or failure) of the game, assessed the effects of these experiences, and proposed actions and plans for the next game session. The abovementioned process is expected to be helpful in high-level meta-cognition training.

It merits further studies to measure and analyze students' behavior in the context of board games. For example, Failing to guide the game effectively by instructor or poor mutual trust among group members may affecting their willingness to participate in discussion due to the social loafing effect [53]. Besides, application of multiple media may improve the impact of board game. Mobile technology is portable and user-friendly and has the functions of augmenting information, presenting multiple representations, and enhancing interaction between people [54,55]. With regards to furthering this study, additional investigations using an enlarged sample size to allow generalizations to be made are underway.

Author Contributions: Conceptualization, P.-H.C., T.-K.Y. and J.-C.T.; Data curation, P.-H.C., T.-K.Y., J.-C.T. and C.-R.L.; Formal analysis, P.-H.C.; Funding acquisition, C.-Y.C.; Investigation, P.-H.C. and J.-C.T.; Methodology, P.-H.C., J.-C.T. and C.-R.L.; Project administration, P.-H.C., T.-K.Y. and C.-Y.C.; Resources, C.-R.L. and C.-Y.C.; Supervision, C.-Y.C.; Validation, T.-K.Y. and C.-R.L.; Visualization, P.-H.C.; Writing-original draft, P.-H.C. and T.-K.Y.; Writing-review \& editing, T.-K.Y. and C.-Y.C.

Funding: This work was financially supported by National Science Council of Taiwan under contracts the MOST 107-2634-F-008-003 and the "Institute for Research Excellence in Learning Sciences" of National Taiwan Normal University (NTNU) from The Featured Areas Research Center Program within the framework of the Higher Education Sprout Project by the Ministry of Education (MOE) in Taiwan.

Conflicts of Interest: The authors declare no conflict of interest.

\section{References}

1. Bergkamp, G.J.J.; Orlando, B.; Burton, I. Change: Adaptation of Water Resources Management to Climate Change; IUCN: Gland, Switzerland, 2003.

2. Council for Economic Planning and Development. Adaptation Strategy to Climate Change in Taiwan; Council for Economic Planning and Development: Taipei, Taiwan, 2012.

3. Ford, J.D.; Berrang-Ford, L.; Paterson, J. A systematic review of observed climate change adaptation in developed nations. Clim. Chang. 2011, 106, 327-336. [CrossRef]

4. Tilbury, D. Environmental education for sustainability: Defining the new focus of environmental education in the 1990s. Environ. Educ. Res. 1995, 1, 195-212. [CrossRef]

5. Wessel, M.R. Science and Conscience; Columbia University Press: New York, NY, USA, 1980.

6. Salerno, F. Adaptation Strategies for Water Resources: Criteria for Research. Water 2017, 9, 805. [CrossRef]

7. OECD. OECD Studies on Water Water and Climate Change Adaptation: Policies to Navigate Uncharted Waters; OECD Publishing: Paris, France, 2013.

8. Hines, J.M.; Hungerford, H.R.; Tomera, A.N. Analysis and synthesis of research on responsible environmental behavior: A meta-analysis. J. Environ. Educ. 1987, 18, 1-8. [CrossRef]

9. Martin, D.; Bélanger, D.; Gosselin, P.; Brazeau, J.; Furgal, C.; Déry, S. Drinking water and potential threats to human health in Nunavik: Adaptation strategies under climate change conditions. Arctic 2007, 60, $195-202$. [CrossRef] 
10. Yang, Y.; Hsu, M. Perception and communication of environmental risk: A case study of situational publics regarding global warming. Chin. J. Commun. Res. 2012, 22, 169-210.

11. Kim, J.-N.; Grunig, J.E.; Ni, L. Reconceptualizing the communicative action of publics: Acquisition, selection, and transmission of information in problematic situations. Int. J. Strat. Commun. 2010, 4, 126-154. [CrossRef]

12. Sadler, T.D. Informal reasoning regarding socioscientific issues: A critical review of research. J. Res. Sci. Teach. 2004, 41, 513-536. [CrossRef]

13. Sweeney, L.B.; Sterman, J.D. Bathtub dynamics: Initial results of a systems thinking inventory. Syst. Dyn. Rev. 2000, 16, 249-286. [CrossRef]

14. Kali, Y.; Orion, N.; Eylon, B.S. Effect of knowledge integration activities on students' perception of the Earth's crust as a cyclic system. J. Res. Sci. Teach. 2003, 40, 545-565. [CrossRef]

15. Schaper, M. The Challenge of Environmental Responsibility and Sustainable Development: Implications for SME and Entrepreneurship Academics. In Radical Changes in the World: Will SMEs Soar or Crash? Recontres de St Gallen: St Gallen, Switzerland, 2002; pp. 541-553.

16. Blackburn, W.R. The Sustainability Handbook: The Complete Management Guide to Achieving Social, Economic and Environmental Responsibility; Routledge: Abingdon, UK, 2012.

17. Ogershok, P.R.; Cottrell, S. The pediatric board game. Med. Teach. 2004, 26, 514-517. [CrossRef] [PubMed]

18. Eisenack, K. A climate change board game for interdisciplinary communication and education. Simul. Gaming 2013, 44, 328-348. [CrossRef]

19. Miralles, L.; Moran, P.; Dopico, E.; Garcia-Vazquez, E. DNA Re-EvolutioN: A game for learning molecular genetics and evolution. Biochem. Mol. Biol. Educ. 2013, 41, 396-401. [CrossRef] [PubMed]

20. Spiegel, C.N.; Alves, G.G.; Cardona, T.d.S.; Melim, L.M.; Luz, M.R.; Araújo-Jorge, T.C.; Henriques-Pons, A. Discovering the cell: An educational game about cell and molecular biology. J. Biol. Educ. 2008, 43, 27-36. [CrossRef]

21. Arslan, H.O.; Moseley, C.; Cigdemoglu, C. Taking attention on environmental issues by an attractive educational game: Enviropoly. Procedia Soc. Behav. Sci. 2011, 28, 801-806. [CrossRef]

22. Peppler, K.; Danish, J.A.; Phelps, D. Collaborative gaming: Teaching children about complex systems and collective behavior. Simul. Gaming 2013, 44, 683-705. [CrossRef]

23. Engelstein, G. Gametek: The Math and Science of Gaming; BookBaby: Pennsauken, NJ, USA, 2017.

24. Hinebaugh, J.P. A Board Game Education; R\&L Education: Lanham, MD, USA, 2009.

25. Joyce, B.R.; Weil, M.; Calhoun, E. Models of Teaching; Prentice-Hall: Englewood Cliffs, NJ, USA, 1986; Volume 499.

26. Shaftel, F.R.; Shaftel, G.A. Role-Playing for Social Values: Decision-Making in the Social Studies; Prentice-Hall: Englewood Cliffs, NJ, USA, 1967.

27. Maier, H.R.; McLaughlan, R.G. Use of a roleplay/simulation in environmental engineering education. In Proceedings of Towards Excellence in Engineering Education, Proceedings of the 12th Australasian Conference on Engineering Education, 7th Australasian Women in Engineering Forum; Faculty of Built Environment and Engineering, Queensland University of Technology: Brisbane, Australia, 2001; p. 374.

28. Gee, J.P. What video games have to teach us about learning and literacy. Comput. Entertain. 2003, 1, 20. [CrossRef]

29. Prensky, M. Digital game-based learning. Comput. Entertain. 2003, 1, 21. [CrossRef]

30. Lopes, G.; Kuhnen, R. Game Design Cognition: The Bottom-Up And Top-Down Approaches. Gamasutra: The Art \& Business of Making Games, 2007. Available online: http:/ / www.gamasutra.com/view / feature/ 130542/game_design_cognition_the_.php (accessed on 14 November 2007).

31. Garris, R.; Ahlers, R.; Driskell, J.E. Games, motivation, and learning: A research and practice model. Simul. Gaming 2002, 33, 441-467. [CrossRef]

32. Kiili, K. Educational Game Design: Experiential Gaming Model Revised; Tampere University of Technology: Tampere, Finland, 2005; p. 320.

33. Starks, K. Cognitive behavioral game design: A unified model for designing serious games. Front. Psychol. 2014, 5, 28. [CrossRef] [PubMed]

34. Johnson, D.W.; Johnson, R.T. Cooperative, Competitive, and Individualistic Learning. J. Res. Dev. Educ. 1978, 12, 3-15.

35. Huang, C.-C.; Yeh, T.-K.; Li, T.-Y.; Chang, C.-Y. The idea storming cube: Evaluating the effects of using game and computer agent to support divergent thinking. J. Educ. Technol. Soc. 2010, 13, 180. 
36. Passey, D. Mobile learning in school contexts: Can teachers alone make it happen? IEEE Trans. Learn. Technol. 2010, 3, 68-81. [CrossRef]

37. Cheng, P.H.; Yeh, T.K.; Chang, C.Y. The utility of the board game for structural concept of solar system and learning motivation: An astronomy board game for elementary school students. In Proceedings of the 2016 EASE Conference, Japan, Tokyo, 16-19 October 2006.

38. Bawden, R. Leadership for Systemic Development; University of Western Sydney: Hawkesbury, ON, Canada, 1997.

39. Sterling, S. Higher education, sustainability, and the role of systemic learning. In Higher Education and the Challenge of Sustainability; Springer: Berlin, Germany, 2004; pp. 49-70.

40. Connolly, T.M. Psychology, Pedagogy, and Assessment in Serious Games; IGI Global: Pennsylvania, PA, USA, 2013.

41. Hsu, S. The effects of an undergraduate environmental education course on environmental action and associated environmental literacy variables. Chin. J. Sci. Educ. 2003, 11, 97-119.

42. Cohen, J. Statistical Power Analysis for the Behavioural Sciences; Erlbaum: Hillsdale, NJ, USA, 1988.

43. Cohen, J. A power primer. Psychol. Bull. 1992, 112, 155. [CrossRef] [PubMed]

44. Birenbaum, M. Assessment and instruction preferences and their relationship with test anxiety and learning strategies. High. Educ. 2007, 53, 749-768. [CrossRef]

45. Chang, C.Y.; Yeh, T.K.; Barufaldi, J.P. The positive and negative effects of science concept tests on student conceptual understanding. Int. J. Sci. Educ. 2010, 32, 265-282. [CrossRef]

46. Assaraf, O.B.Z.; Orion, N. Development of system thinking skills in the context of earth system education. J. Res. Sci. Teach. 2005, 42, 518-560. [CrossRef]

47. Osbaldiston, R.; Schott, J.P. Environmental sustainability and behavioral science: Meta-analysis of proenvironmental behavior experiments. Environ. Behav. 2012, 44, 257-299. [CrossRef]

48. Sadler, T.D.; Donnelly, L.A. Socioscientific argumentation: The effects of content knowledge and morality. Int. J. Sci. Educ. 2006, 28, 1463-1488. [CrossRef]

49. Ericsson, K.A.; Krampe, R.T.; Tesch-Römer, C. The role of deliberate practice in the acquisition of expert performance. Psychol. Rev. 1993, 100, 363. [CrossRef]

50. Chiang, Y.-T.; Fang, W.-T.; Kaplan, U.; Ng, E. Locus of Control: The Mediation Effect between Emotional Stability and Pro-Environmental Behavior. Sustainability 2019, 11, 820. [CrossRef]

51. Chen, M.F. An examination of the value-belief-norm theory model in predicting pro-environmental behaviour in Taiwan. Asian J. Soc. Psychol. 2015, 18, 145-151. [CrossRef]

52. Ajzen, I. From intentions to actions: A theory of planned behavior. In Action Control; Springer: Berlin, Germany, 1985; pp. 11-39.

53. Wang, H.-C.; Rosé, C.P.; Chang, C.-Y. Agent-based dynamic support for learning from collaborative brainstorming in scientific inquiry. Int. J. Comput. Support. Collab. Learn. 2011, 6, 371. [CrossRef]

54. Liou, W.-K.; Bhagat, K.K.; Chang, C.-Y. Beyond the flipped classroom: A highly interactive cloud-classroom (HIC) embedded into basic materials science courses. J. Sci. Educ. Technol. 2016, 25, 460-473. [CrossRef]

55. Whalen, T. Playing well with others: Applying board game design to tabletop display interfaces. In Proceedings of the ACM Symposium on User Interface Software and Technology, Vancouver, BC, Canada, 2-5 November 2003.

(C) 2019 by the authors. Licensee MDPI, Basel, Switzerland. This article is an open access article distributed under the terms and conditions of the Creative Commons Attribution (CC BY) license (http:/ / creativecommons.org/licenses/by/4.0/). 